\title{
Evaluation of phytoextracts against seed mycoflora of Indian bean (Lablab purpureus L.) cultivars under in vitro condition
}

Dhara R. Prajapati and P.R. Patel*

Department of Plant Pathology, N. M. College of Agriculture, Navsari Agricultural University, Navsari (Gujarat) India

\section{ARITCLE INFO}

Received : 20.02 .2020

Revised : 03.03.2020

Accepted : 16.03 .2020

\section{KEY WORDS :}

Indian bean, Phytoextracts, Mycoflora, Seed, Leaves

*Corresponding author:

Email : prpfrs.nau@gmail.com

\begin{abstract}
In vitro evaluation of seven phytoextracts as seed dresser against seed mycoflora of Indian bean revealed custard apple leaf extract proved to be most effective with least number of fungal infected seeds followed by turmeric rhizome extract. Neem leaves extract also proved their potential against seed mycoflora.

How to view point the article : Prajapati, Dhara R. and Patel, P.R. (2020). Evaluation of phytoextracts against seed mycoflora of Indian bean (Lablab purpureus L.) cultivars under in vitro condition. Internat. J. Plant Protec., 13(1) : 67-70, DOI : 10.15740/HAS/IJPP/13.1/67-70, Copyright@ 2020: Hind Agri-Horticultural Society.
\end{abstract}

